\title{
HRADBA JAKO KULTURNĚHISTORICKÝ PROBLÉM: BAROKNÍ FORTIFIKACE PRAŽSKÉHO LEVOBŘEŽÍ V PÍSEMNOSTECH FORTIFIKAČNÍ KOMISE ČESKÉHO MÍSTODRŽITELSTVÍ
}

\author{
PAVLA HASILOVÁ - JAN HASIL
}

\begin{abstract}
Abstrakt: Předkládaná esej se zamýšli nad současnými přistupy české archeologie k problematice stálých fortifikaci komplexnich sídelnich areálů formou př́padové analýzy archivnich dokumentů z provenience fortifikačni komise Českého mistodržitelství, zejména z obdobi vlády Karla VI., které se dotýkaji opevnění pražského levobřeži, tj. Malé Strany a Hradčan. Analyzované dokumenty názorným způsobem postihuji praktické aspekty výstavby, konstrukce i oprav fortifikace - artefaktu, ale i každodenni okolnosti soužití malostranské a hradčanské komunity „, s hradbou“. Pražské barokni hradby se tak ukazuji jako samostatný areál specifických aktivit, tedy nejen jako formálni znak sídliště urbánního charakteru, pro něž představovaly ve svých každodennich praktických dopadech spíše zátěž.
\end{abstract}

Klíčová slova: postmedievální archeologie - České místodržitelství - Karel VI. - novověké fortifikace Praha-Malá Strana-Praha-Hradčany.

Fortifications as Cultural and Historical Phenomena: Baroque fortification of the left bank of the River Vltava, Prague in the documents of the fortification committee of the Czech Vicegerency

\begin{abstract}
This paper discusses the current approaches of Czech archaeology to the subject of the permanent fortification of settlement complexes, through case analysis of archive documents from the provenance of the fortification committee of the Czech Vicegerency, notably those from the period of the reign of Charles VI that are associated with the fortification of the left bank of the River Vltava, i.e. the Mala Strana and Hradčany quarters. The analyzed documents illustrate the practical aspects of the building, structure and repairs of fortifications as artefacts, as well as the everyday realities of the "cohabitation" of the Malá Strana and Hradčany communities with the "wall". Prague baroque fortifications emerge as an autonomous area of specific activities, i.e. not only a feature of an urban unit for which they actually meant, in their practical everyday effect, an obstacle.
\end{abstract}

Key words: post-medieval archaeology - Czech Vicegerency - Charles VI - modern-age fortifications Prague-Malá Strana - Prague-Hradčany.

\section{Hradba jako kulturněhistorický problém}

Jednou z konstant středoevropské, a tedy i české archeologie je dlouhodobý zájem o stálé fortifikační systémy komplexních sídlištních areálů (např. hradišt', oppid či měst; stranou tak nadále zůstávají veškerá jednoúčelová opevnění, jako jsou např. obléhací tábory, i samostatné fortifikované areály, charakteristicky tedy hrady či tvrze, a dále fortifikační objekty, které byly zpravidla součástí vyšších celků, např. forty či rozličné vojenské kryty). Přitom ovšem - přijmeme-li jistou míru karikujícího sdělení - lze tvrdit, že tomuto fenoménu je věnována pozornost v odborných textech i více či méně formálních diskusích převažující měrou ze dvou aspektů: jde jednak o otázky spojené s jejich konstrukcí (např. Dresler 2011; Procházka 2009 či Kos 2013), jednak o studium opevněných areálů jako takových, přičemž hradba je v tomto případě chápána primárně jako jejich formální znak (charakteristicky Bartošková 2014; Ettel 2001; Richter 1982), v případě pravěkých a raně středověkých opevněných lokalit často dokonce jako jediná pochopitelná struktura konstituující hradiště, viereckschanze, oppidum či raně středověký hrad. Pouze v případě studií rozsáhlejších sídelních aglomerací raně středověkého období (napřs. Praha - Čiháková-Havrda 2009; Stará Boleslav - Boháčová a kol. 2003; Žatec - Čech 2008), výrazných koncentrací raně středověkých fortifikovaných lokalit (napřr. tzv. přemyslovská středočeská doména - naposledy Štefan-Hasil 2014), novověkých pevností (např. Kupka a kol. 2001) či v textech věnovaných středověkým a novověkým městům (např. Razím 2001a) se lze setkat 
s chápáním fortifikace jako svébytného areálu lidských aktivit. Vesměs však jde pouze o $a d$ hoc prŕístup daný profilací a kompetencí dostupných pramenů, či naopak řešenou otázkou. Lze tak konstatovat, že hradba jako problém kulturněhistorického studia (k pojmu viz Burke 2011; Daniel 2005) nebyla českou archeologií doposud tematizována. Př́čin této skutečnosti je patrně možno jmenovat hned několik: je to jednak bezesporu setrvačnost tradičních pojetí, jednak nazírání vzniku a zániku fortifikací prizmatem archeologické události (k pojmu viz Neustupný 2007) a v neposlední řadě stále velmi pevné konceptuální pouto se sídelním areálem, jejž fortifikace uzavírá (vzpomeňme na tomto místě revoluce v poznávání center doby laténské po identifikaci lokalit typu Roseldorf - Němčice či Lovosic na počátku 90. let - Salač 2011).

Má-li být hradba vnímána uceleně, nelze ji nahlížet pouze v jejích primárních úlohách, nýbrž i v sekundárních dopadech na její okolí, protože jakkoliv fortifikace vzniká jako stavební opatření či jejich kombinace sloužící zpravidla současně k právnímu vymezení určitého areálu, fiskální a policejní regulaci jeho př́ístupnosti a konečně k jeho vojenské obraně, má její existence i nesporné vedlejší a nechtěné účinky na své okolí. Již jen příprava výstavby hradeb znamenala výrazný zásah do prostorového i právního uspořádání krajiny i života komunit v ní usedlých a počátek fyzické stavby potom přinesl i příchod nových skupin obyvatelstva a zátěž např. v podobě dopravních omezení či přechodného i dlouhodobého záboru pozemků. Interakce mezi hradbou a obyvateli města však její výstavbou zdaleka nekončila; pozměněný mikroregionální vodní management si vyžádal dodatečné stavební akce, zaběhlé využití některých ploch v sousedství hradebního pásma zůstalo natrvalo omezené či zcela vyloučené, sama hradba pak vyžadovala průběžnou údržbu a reparační zásahy, na kterých se obyvatelstvo opevněného sídla na základě tržních či jiných socioekonomických mechanismů podílelo. Lze tak doslova hovořit o ,životě s hradbou“, a dokonce i o ,životě hradby“. Bylo by tedy možno obecně definovat komplexní systém společenských i fyzických činitelů a jejich vztahů, který by postihoval historický proces života hradby od její ideové koncepce k výstavbě (determinované lokálními podmínkami), volbu konkrétních fortifikačních prvků, jejich konstrukci, výstavbu, chátrání, opravy, válečná poškození, cílená rozšíření, zkrátka veškeré - i zcela marginální - stopy lidských aktivit spojených s areálem hradby, a to až po ztrátu funkce, fyzický zánik i ztrátu významu prostorového, právního i strategického členění vyjádřeného právě fortifikační linií, popř. distribucí fortifikovaných a fortifikačních objektů v krajině.

Je zřejmé, že na základě hmotné pramenné báze samé podobný model vzniknout nemůže, nebot' sebedelší a vnitřní logikou zdánlivě „,provázaný“ řetězec archeologických událostí nevytváŕí jednoznačně a opakovaně identifikovatelný diskurs, jak tento pojem chápe postmoderní hermeneutika (viz např. Ricoeur 1997, 23). Vypracován proto může být na základě těch fortifikací, u kterých je jejich diskursivní (a tedy zpravidla „multikauzální“) podstata zachycena alternativní, tj. písemnou pramennou evidencí. Př́ínosem v tomto směru může být ve středoevropském prostředí archeologie modernity (výzkum tzv. železné opony či československého opevnění z druhé poloviny 30. let) i poznávání fortifikací novověkého období. Pro období starší, pro která nedisponujeme dostatečným penzem písemné evidence, pak takto založený teoretický koncept zůstává $\mathrm{v}$ platnosti jako model, $\mathrm{v}$ jehož rámci lze provazovat zjištěné archeologické poznatky a vztáhnout je k úvahám např. o komplexitě tehdejší společnosti.

Prvním krokem na cestě $\mathrm{k}$ takto založenému studiu fenoménu opevňování je uvědomění si těch aspektů „života hradby“, kterým se současná archeologická bádání z různých důvodů nevěnují. Cílem následujících stránek tak bude sonda do pramenné báze týkající se zpravidla opomíjených aspektů přítomnosti hradby v krajině - fyzických i sociálních. Pro účely takto pojaté prrípadové analýzy bylo zvoleno barokní opevnění pražského levobřeží, tedy Malé Strany a Hradčan, zejména jak jej postihují písemnosti vzniklé v pozdním období jeho trvání a dostaveb v rámci činnosti fortifikační komise Českého místodržitelství, uložené z větší části v Národním archivu ČR a částečně též v Státním oblastním archivu v Třeboni. Uvedené prameny pocházející převážně z doby vlády Karla VI. (1711-1740; znalosti o výstavbě malostranského opevnění ve druhé polovině 17. století shrnuje Vlček-Čiháková 1999, 116-117, stavební aktivity v první polovině 18. století tak jsou komplexněji zpracovány vůbec poprvé) vycházejí primárně 
z potřeb správněhistorického studia a nepostihují svou charakteristikou průběžný stavební vývoj levobřežní bastionové fronty, nebot' místodržitelská fortifikační komise neprováděla vlastní technickou realizaci stavby. Představují však naopak cestu k poznání ideových, společenských a správních souvislostí hradebního tělesa, nebot’ to byl právě panovník a české stavy, kteří společně rozhodli o vzniku opevnění, a byla to místodržitelská fortifikační komise, která rámcově, tedy finančně, právně a správně, výstavbu a provoz hradeb zajištovala.

\section{Barokní opevnění pražského levobřeží: stručná charakteristika}

Pražská levobřežní aglomerace zahrnovala hned několik symbolicko-ideologicky významných areálů, které hrály nejpozději od 10. století podstatnou úlohu v duchovním a politickém životě Čechů a Čech. Významná pak samozřejmě byla i hospodářská a v neposlední řadě komunikační úloha. Dlouhodobé prolínání všech těchto funkcí tak dalo vzniknout sídelnímu celku s mimořádnou symbolickou a duchovně-ideologickou hodnotou, již český kníže, později český král a nakonec české stavy coby nositelé zemské identity artefaktuálně vyjadřovali v podobě různých fází fortifikací pražského levobřeží. Zpočátku, v období raného středověku, byly oba sídelní areály pražského levobřeží fortifikovány odděleně (viz např. Havrda-Tryml 2013, obr. 44), teprve vrcholně středověká gotická hradba - snad v důsledku rozvoje obléhací techniky v západní a jižní Evropě, s nímž byl její stavitel, císař Karel IV., patrně obeznámen - dala vzniknout nové koncepci prostorového vymezení pražských levobřežních sídelních celků (viz např. Havrda-Tryml 2013, obr. 48). Zásadní inovace spočívala v zahrnutí strategicky významného petřínského návrší (viz Razím 2001) a západního předpolí Pražského hradu (Hradčan), přičemž obě tyto fronty byly propojeny v prostoru Strahova. Toto pojetí obranného perimetru levobřežních pražských měst později bez výrazných proměn převzala hradba barokní (ta však nově zahrnula i severní předpolí Pražského hradu), která ostatně některé součásti staršího období přímo inkorporovala (zejména tzv. Hladovou zed’ na petřínském úbočí a Malostranskou mosteckou věž, již je coby jednu z bran do opevněného areálu třeba rovněž pokládat za podstatnou součást fortifikace - obr. 1:F, 11).

K prvotním úvahám o výstavbě nového opevnění pražských měst došlo ještě během třicetileté války, v roce 1641, ovšem ještě v době švédského vpádu roku 1648 spoléhala pražská obrana především na gotické hradby bezmála tři století výrazněji nemodernizované, doplněné o polní opevňovací práce (blíže viz Razím 2001; Vlček-Čiháková 1999, 115-116). Po skončení třicetileté války bylo opevnění hlavně Starého a Nového Města v tristním stavu a podobná situace pak panovala $\mathrm{v}$ Chebu ( $\mathrm{k}$ událostem $\mathrm{v}$ tomto městě na konci třicetileté války viz Kortus 2008), který jako centrum ř́išského zástavního území požíval až do osvícenských reforem specifické státoprávní postavení (Siegl 1918; Kubů 2006). Císař Ferdinand III. proto rozhodl dekretem z 3. června 1652 o vybudování tzv. zemských pevností (k tomuto fenoménu viz Kupka a kol. 2001, 198), přičemž ale na vybudování nového opevnění Malé Strany nebylo v jeho plánu pamatováno. Proto se zemské stavy rozhodly zorganizovat tuto výstavbu samy. Stavba nového opevnění tak byla rozdělena na tři nezávislé oddíly - separata corpora. Do prvního patřilo opevnění Starého a Nového Města a stavba samostatně stojící citadely na Vyšehradě, druhým bylo opevnění Malé Strany a Hradčan a třetím pak nové opevnění města Chebu. Tyto tři části neměly žádné společné zaměstnance, dělníky ani stavební mistry a hlavně měly zcela oddělené finance, vzhledem k tomu, že jejich stavebníky byly v zásadě rozdílné subjekty. Jediným společným činitelem byl dohlížecí inženýr (obseher Ingeneur), vybíraný a delegovaný na toto místo centrálním vojenským úřadem ve Vídni - Dvorskou válečnou radou (Hofkriegsrat), který měl kontrolovat vojenskou a strategickou stránku věci. Ve vojenských záležitostech rozhodoval a v př́ípadě obléhání pak jednotně velel - vojenský velitel Prahy (SOA T; Hasilová, v př́ípravě).

V historické retrospektivě je třeba konstatovat, že vojenská hodnota zemských pevností nebyla valná a že to bylo paradoxně rakouské vojsko, které tyto fortifikace obsazené francouzskými jednotkami obléhalo v době válek o rakouské dědictví, resp. za sedmileté války. V té době však již ztratily statut zemských pevností, nebot' ty byly roku 1749 zrušeny a právně převedeny 
na běžné městské hradby; jako takové pak sehrálo opevnění Prahy i epizodní úlohu v revolučních bojích roku 1848.

Od roku 1871 (Kupka a kol. 2001, 243) pak probíhala demolice pražských hradeb, která postihla výrazněji pražské pravobřeží, zatímco opevnění malostranského břehu je dnes dochováno zhruba z 33 \% v podobě stojících armovaných objektů a z dalších asi 18 \% jako zemní tělesa

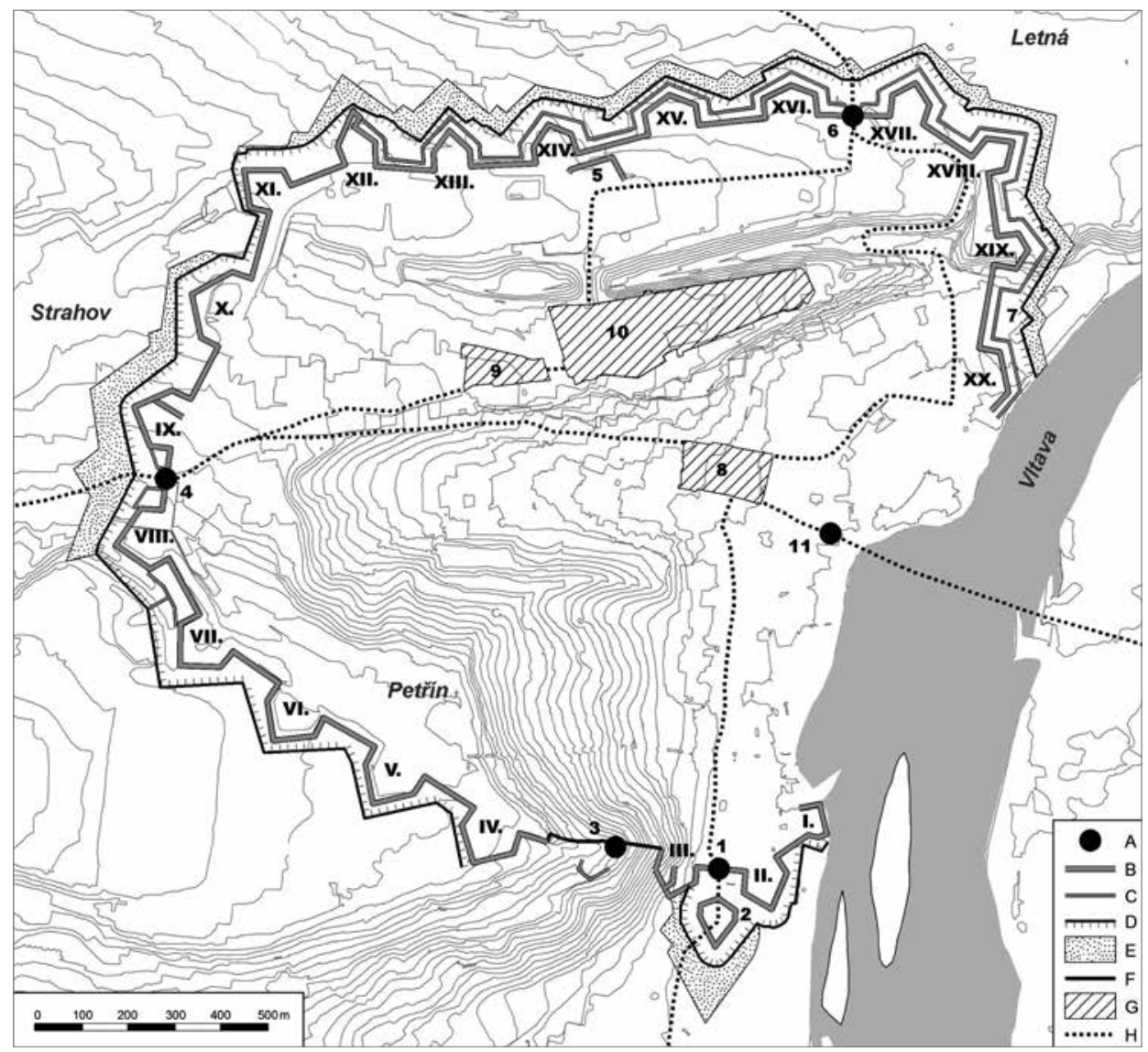

Obr. 1. Schéma barokního opevnění pražského levobřeží: A - významné fortifikační objekty, B - bastionová fronta, C - hrana bermy, D - hrana kontreskarpy, E - předpokládaný rozsah glacis, F - inkorporovaná část gotické hradby (tzv. „Hladová zed"“), G-významné polohy v zástavbě Hradčan a Malé Strany, H - významné komunikační linie. Bastiony (zachováno pủvodní číslování): I. - sv. Jan; II. - sv. Jakub; III. - sv. Dominik; IV. - sv. Karel; V. - sv. Vavřinec; VI. - sv. Vojtěch; VII. - sv. Norbert; VIII. - Špitálský; IX. - Strahovský; X. - sv. Františka Borgia; XI. - Hvězda; XII. - Panny Marie; XIII. - sv. Benedikt; XIV. - sv. Václav; XV. - Všech Svatých; XVI. - sv. Jiří; XVII. - sv. Ludmila; XVIII. - sv. Tomáš; XIX. - sv. Máří Magdalena (tzv. „Mariánská hradba“); XX. - sv. Ignác. 1 - Újezdská brána, 2 - Újezdský ravelin, 3 - dělová terasa (tzv. „bastion sv. Josefa“), 4 - Strahovská (Říšská) brána, 5 - kavalír, 6 - Písečná (Karlova) brána, 7 - tzv. Jezuitská zahrada, 8-Malostranské náměstí, 9 - Hradčanské náměstí, 10 - areál Pražského hradu, 11 - Malostranská mostecká věž. Podle Hergetova plánu, NA, SČM, 1733/X/d/6a a Kašička-Lacinger 2005 s přihlédnutím k dobové ikonografii na základě Stabilního katastru rektifikoval J. Hasil. Zpracováno v rámci VRE IIS_APP, datový podklad (C) IPR hl.m. Prahy.

Abb. 1. Schema der barocken Befestigung des linken Prager Moldauufers: A - bedeutende Fortifikationsobjekte, B - Bastionärfront, C - Bermenkante, D - Kante der Kontreeskarpe, E - angenommener Umfang der Glacis, F - inkorporierter Teil der gotischen Stadtmauer (sog. „Hungermauer"), G - wichtige Lagen in der Bebauung des Hradschins und der Kleinseite, H - wichtige Wegelinien. Bastionen (unter Beibehaltung der ursprünglichen Nummerierung): I. - HI. Johannes; II. - HI. Jakob; III. - HI. Dominikus; IV. - HI. Karl; V. - HI. Laurentius; VI. - HI. Adalbert; VII. - HI. Norbert; VIII. - Spitalbastion; IX. - Strahover Bastion; X. - HI. Franz de Borja; XI. - Sternbastion; XII. - Jungfrau Maria; XIII. - HI. Benedikt; XIV. - HI. Wenzel; XV. - Allerheiligen; XVI. - HI. Georg; XVII. - HI. Ludmilla; XVIII. - HI. Thomas; XIX. - HI. Maria Magdalena (sog. „Marienmauer“); XX. - HI. Ignatius. 1 - Aujest-Tor, 2 - Aujest-Ravelin, 3 - Kanonenterrasse (sog. „Joseph-Bastion“), 4 - Strahov-Tor (Reichstor), 5 - Kavalier, 6 - Sandtor (Karlstor), 7 - sog. Jesuitengarten, 8 - Kleinstädter Ring, 9 - Hradschiner Platz, 10 - Areal der Prager Burg, 11 - Kleinseitner Brückenturm. Nach Hergetscher Plan, NA, SČM, 1733/X/d/6a und Kašička-Lacinger 2005 unter Berücksichtigung der zeitgenössischen Ikonographie anhand des Stabilen Katasters rektifiziert von J. Hasil. Ausgearbeitet im Rahmen der Virtuellen Forschungsumgebung Integriertes Informationssystem der archäologischen Quellen Prags, Datenvorlage ( $)$ Institut für Planung und Entwicklung der Hauptstadt Prag. 
v různém stupni degradace (viz obr. 2), zachovány jsou i dva samostatné objekty, dělová terasa při brance v inkorporované části gotické hradby na Petříně (obr. 1:3) a Písečná brána (v literatuře nesprávně uváděna jako Písecká) severně od Pražského hradu (obr. 1:6). Relikty pražského levobřežního barokního opevnění jsou od roku 1958 kulturní památkou, která však postihuje jen část někdejšího fortifications-districtu, nebot' chráněnou památkou jsou pouze relikty vlastní bastionové fronty, zatímco prostor bermy, eskarpy, kontreskarpy a glacis již jakkoliv chráněn nebyl a není. V současnosti se barokní fortifikační pásmo stává předmětem záchranných archeologických výzkumů (viz např. Jeřáb 2000; Bartošová-Herichová-Kašička-Tomková 2010), pozůstatkům levobřežní hradby se však ze strany památkové péče nedostává srovnatelné systematické pozornosti, jaká je věnována jiným obdobným objektům na území Čech (srov. Slavík a kol. 2014).

\section{Přípravné práce a omezení spojená se stavbou}

Výstavba komplexní barokní fortifikace Prahy jako zemské pevnosti byla zahájena v roce 1653. Nelze tvrdit, že by stavba probíhala postupně, lineárně od jednoho opevňovacího prvku

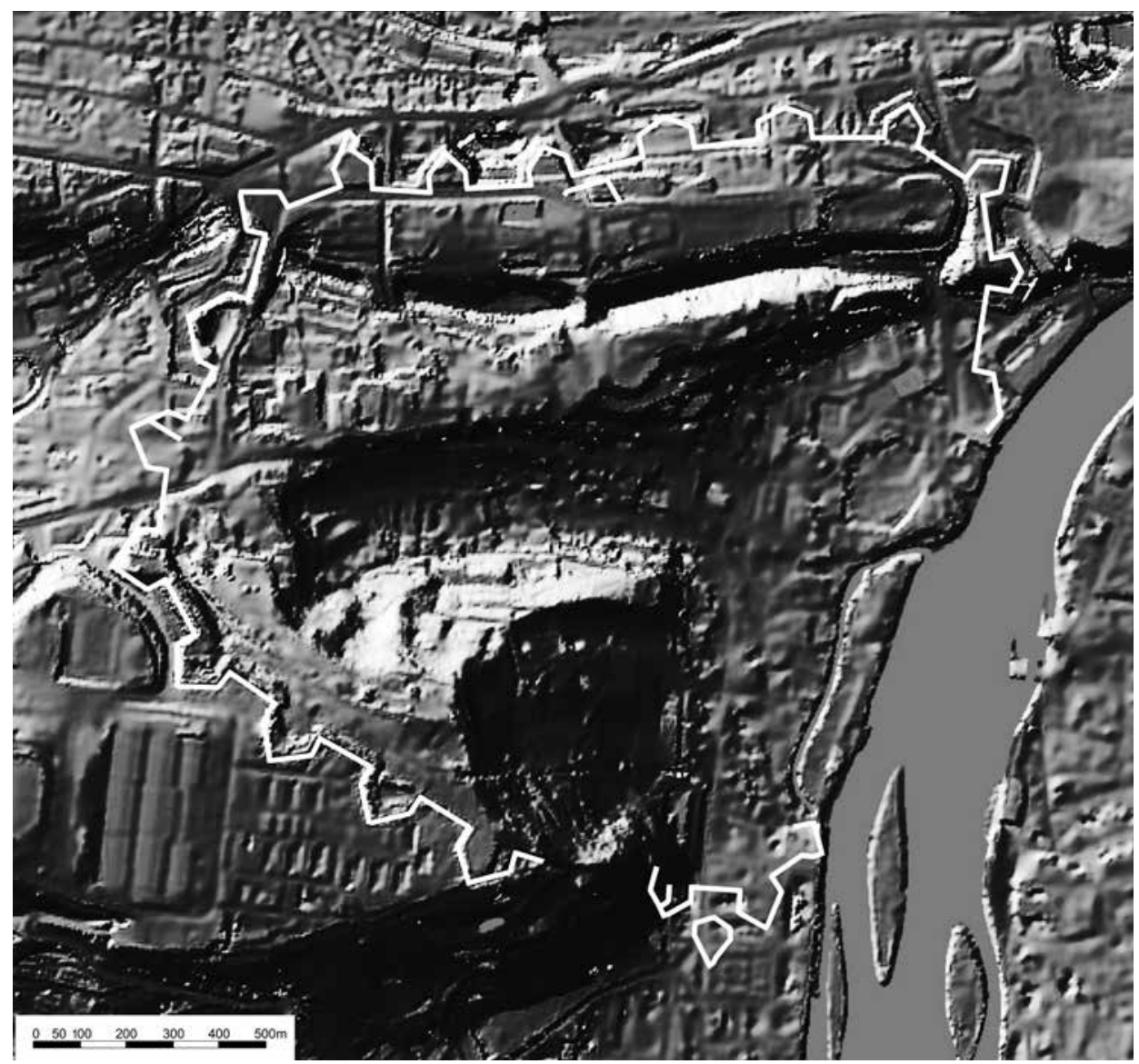

Obr. 2. LLS snímek 4. generace ukazuje relativně vysokou míru terénního dochování barokního opevnění pražského levobřeží. Naznačen původní průběh bastionové fronty. Sestavil J. Hasil, data $\odot$ Č́ZK.

Abb. 2. Die Laserscanning-Aufnahme der 4. Generation zeigt einen relativ hohen Geländeerhaltungsgrad der barocken Befestigungsanlage am linken Prager Moldauufer. Ursprünglicher Verlauf der Bastionärfront durch weiße Linie angedeutet. Erstellt von J. Hasil, Daten $\odot$ Tschechisches Amt für Landesvermessung und Kataster. 
k druhému. Pracovalo se vždy na několika místech současně, v plánech a výhledech stavebních prací na konkrétní rok tak mohla být třeba jen jedna stěna bastionu apod. Nejprve samozřejmě probíhaly přípravné práce, úprava terénu, poté následovalo vybudování zemních těles, příkopu a kontreskarpy, nakonec byly doplňovány plenty opevnění. Stejně tak bylo opevnění postupně předáváno armádě k užívání; zatímco některé části už byly předány vojsku, jiné úseky hradeb či prvky opevnění byly zatím ve výstavbě.

Velkým problémem se ukázalo získávání pozemků pro stavbu. V okolí stavby se výjimečně pozemky pouze pronajímaly (např. v Eggenberské zahradě v severní části dnešního Smíchova sousedící s Újezdem, kam bylo skládáno dřevo na palisády), avšak většina pozemků musela být vykoupena anebo zabrána. K výkupům pozemků docházelo postupně, tak jak to pokračující stavba vyžadovala. Např́iklad ještě v roce 1734 byla vykoupena vinice nad bastionem sv. Máří Magdaleny (obr. 1:XIX), u tzv. „Judenschantzl“, aby se mohl dokončit tamní příkop a kontreskarpa. Největší problém s majiteli pozemků se ukázal v př́ípadě strahovských premonstrátů (NA, SČM, 1734/III/d/20) při stavbě opevnění okolo tzv. Písečné brány (obr. 1:6). V roce 1734 měla být v této části vybudována „krytá cesta, parkán a plenta kurtiny“, rok předtím se podle plánu vybudovalo vyzdění kolem hlavního př́íkopu až k Strahovskému bastionu (obr. 1:IX), chybělo urovnat předpolí. Mezi bastiony sv. Karla a sv. Norberta (obr. 1:IV-VII) byly dokončeny kurtiny, nebyl ovšem vytvořen př́kop a kontreskarpa, které byly považovány vzhledem k okolnímu terénu za nutné. Podloží zde bylo tvrdé nebo se šlo prrímo na skálu. K těmto úpravám bylo proto nutné vylámat či odstřelit značný objem kamene. Pozemky pod celou touto linií patřily ovšem pod dominikální panství strahovského kláštera a preláti nesouhlasili s jakýmikoliv terénními úpravami. Tím by však na několika místech docházelo k tomu, že by se hradba dala přes skálu snadno přelézt. Místodržitelská fortifikační komise proto s premonstráty dlouhodobě vyjednávala, nicméně aniž bylo dosaženo výraznějšího úspěchu. Preláti pouze souhlasili s tím, že až bude na konkrétních místech nutný odstřel skály, má je kameník osobně informovat o tomto záměru, a konvent pak sám zváží, zda na vybraném místě změny povolí.

Pro zásobování stavby cihlami byly vybudovány fortifikační cihelny. Na stavební materiál pro malostranské opevnění se odebírala hlína z hliníků v těsné blízkosti stavby, od roku 1718 se hlína začala těžit v hliníku v bývalé Granwaldské vinici, jež se nacházela hned za Újezdskou bránou, pozemky byly majitelce Anně Terezii Convayin, rozené Granwaldt, zabrány téhož roku. K proplacení náhrady za tyto pozemky došlo ovšem až roku 1731 (NA, SČM, 1731/III/d/12, 1719/I/d/55/7). Fortifikační cihelny měly sloužit výhradně pro stavbu opevnění, nicméně se odtud běžně prodávalo i obyvatelům města. To byla ovšem nevítaná konkurence pro obecní cihelnu, která přicházela o zisk. Roku 1731 byl proto prodej stavebního materiálu měšt’anům přísně zakázán a cihly byly vydávány pouze na průkaz z fortifikatoria (NA, SČM, 1731/III/d/12).

Vlastní výstavbě opevnění předcházely rozsáhlé zemní práce i demolice starších konstrukcí. Aby mohla podle nových plánů vzniknout moderní fortifikace, musely jí některé starší části udělat místo. Fůry sutě ze zbouraných strážnic, mýtných domků a jiných staveb měly být voženy k zasypání prostor mezi starými a novými hradbami. Na druhou stranu, při hloubení nových př́íkopů bylo vytěženo mnoho země, která často po dlouhou dobu zůstávala v blízkosti opevnění a několikrát muselo být urgováno odvezení těchto nechtěných „náspư“, které by jinak snižovaly obrannou funkci hradeb (NA, SČM, 1734/III/d/21, 22, 23).

Častou nepř́ijemností, kterou vyvolávaly jak prrípravné práce, tak i stavba sama, byla nesjízdnost silnice kvůli sesuvům půdy, naplavení bahna ze zemních prací při prudkých deštích nebo zaplavování soukromých pozemků vodou svedenou ze stavby. Např́íklad v roce 1730 se stala nesjízdnou silnice vedoucí od Strahovské brány kvůli stavbě fortifikace, formani se proto této cestě vyhýbali a objížděli bránu, na což si stěžovaly místní úřady, jelikož tak přicházely o zisk z mýta (NA, SČM, 1731/VI/d/40). Na tzv. Mariánské hradbě (obr. 1:XIX) byla v roce 1732 vybudována výpust' vody, aby nedocházelo k podmáčení zdi vodou stékající při dešti z letenského návrší dolů. Výpust ovšem odtud odváděla veškerou vodu na pole hraběte Adolfa Bernarda z Martinic, kde kvůli tomu došlo ke škodám na úrodě (NA, SČM, 1733/III/d/60). Martinic si na celou věc samozřejmě stěžoval, k urychlení nápravy si nakonec sám nechal navrhnout technický 


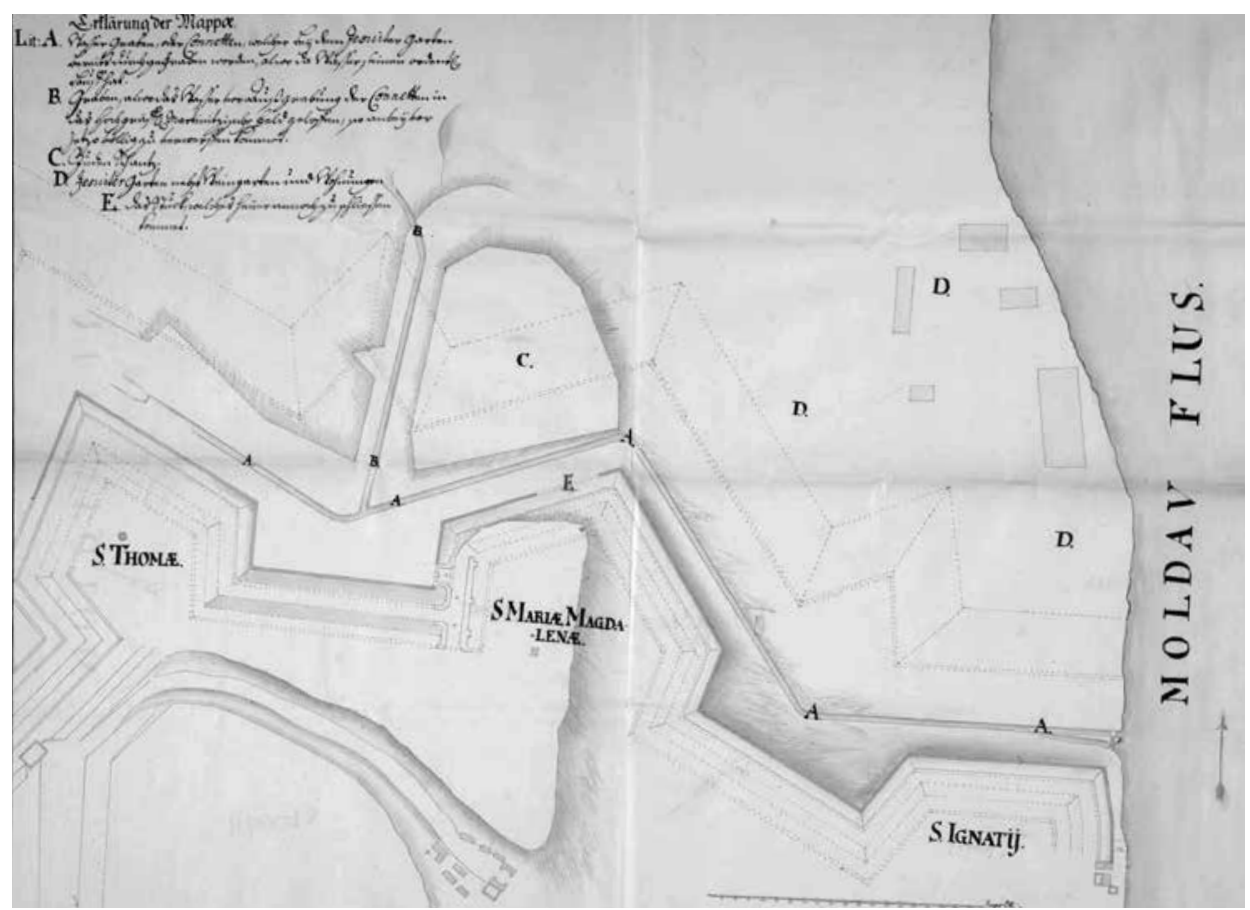

Obr. 3. Plán bastionů sv. Ignáce, Máří Magdaleny a Tomáše z roku 1733 s vlastním návrhem hraběte Bernarda Adolfa z Martinic na regulaci vodního režimu. NA, SČM, 1733/X/d/6a.

Abb. 3. Plan der St. Ignatiusbastion, Maria Magdalenenbastion und Thomasbastion aus dem Jahr 1733 mit eigenem Entwurf von Graf Bernhard Adolf von Martinitz für die Regulierung des Wassersystems. NA, SČM, 1733/X/d/6a.

projekt řešení, totiž vybudování kynety kolem postiženého úseku hradby, kam by ústila i odvodňovací strouha (obr. 3).

\section{Stavba opevnění}

Ve chvíli, kdy už probíhala stavba samého opevnění, vytanuly pro stavebníky nové problémy, které bylo třeba řešit. Bylo nutné zajistit kvalitu práce, což nebylo vždy jednoduché. Objevovaly se mj. návrhy na pokračování stavby i v zimních měsících (NA, SČM, 1713/XI/m). Na stavbě fortifikace se měli navíc podílet delikventi odsouzení $\mathrm{k}$ veřejným pracím. Dlouhodobě se volalo po zpř́ísnění trestů, a tedy po uložení těžších prací, které budou delikventi vykonávat. Na stavbu šancí byli přitom určeni, jak to $\mathrm{v}$ té době bylo chápáno, jedni z nejtěžších kriminálníků, heretici. Šlo o nekatolíky z Prahy a okolí, kteří byli usvědčeni z hereze, jejich proces již skončil a byli za př́slušný delikt odsouzeni. Na fortifikačních pracích se mělo dohlížet hlavně na to, aby odsouzenci dále nepraktikovali pobožnosti evangelického vyznání, naopak zde měli být upevněni v katolické víře: ,in denen Principis Fidei Catholicae weithers vestzusetzen“. Práce na opevnění byla chápána spíše jen jako podpůrný a výchovný prostředek. O kontrole kvality jimi odvedené práce se v nařízeních neobjevila žádná zmínka. Na opevňovací práce se navíc posílali nejen muži, ale i ženy a odrostlejší děti (NA, SČM, 1727/IV/d/41, 42).

Jako zásadní problém se $\mathrm{v}$ průběhu výstavby opevnění projevil management srážkové a splaškové vody. Pražské hradby se stavěly původně bez jakéhokoliv odvodňovacího systému a mnohdy se ukázalo až v okamžiku, kdy př́slušná část stavby byla dokončena, že na místech, kde hradba přetíná svah, případně i jinde, při silných, prudkých deštích dochází k podmáčení bastionů a kurtin. V okolí pražského opevnění se proto začali vyskytovat rouraři (Röhrgeselle), 


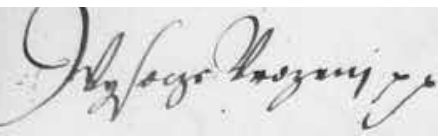

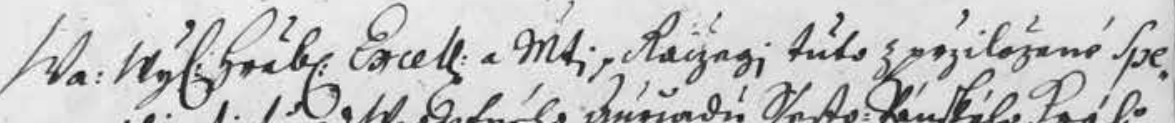

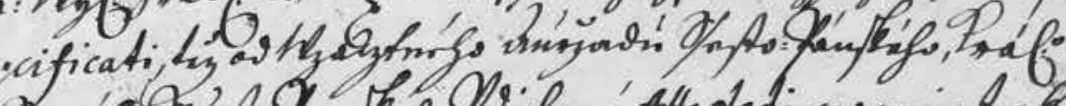

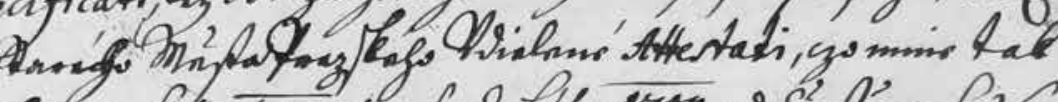

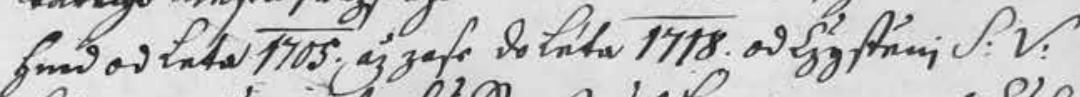

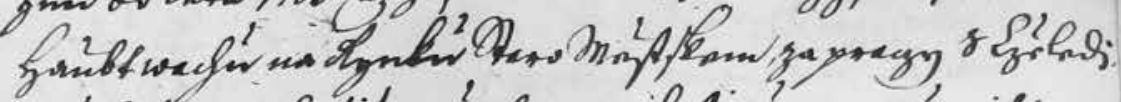

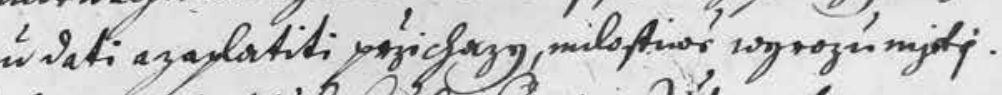

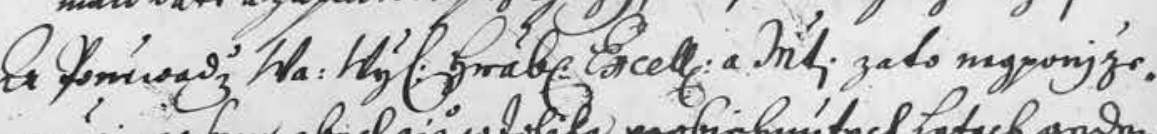

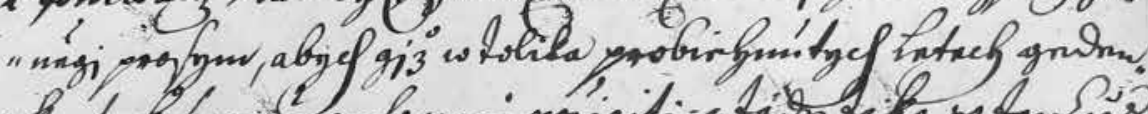

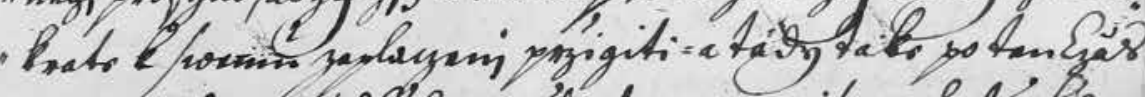

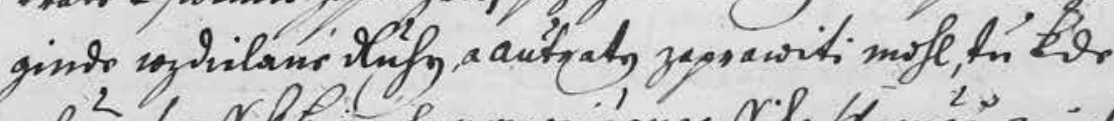

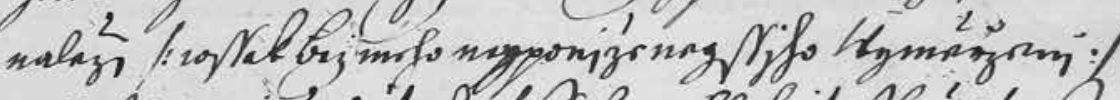

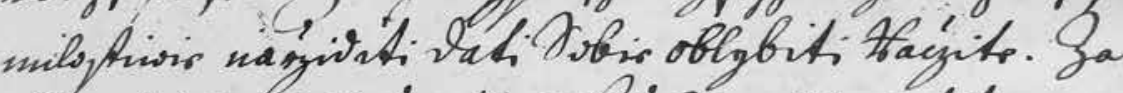

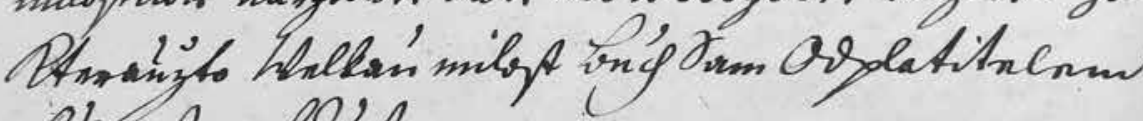

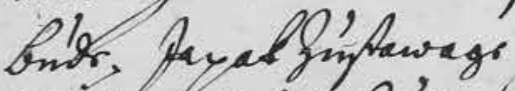

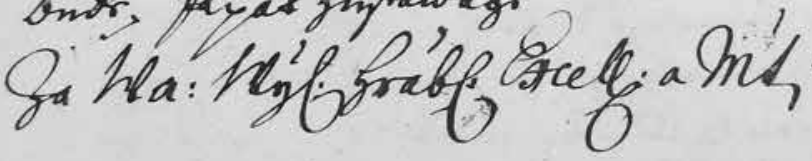

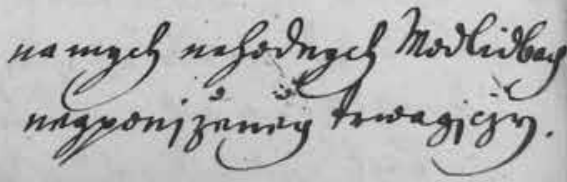

Mantin Tan max foform Bratephtival.

Obr. 4. Žádost pohodného Martina Leyssnera o zaplacení dlužné částky za čištění strážnice v letech 1705-1718 (1723). NA, SČM, $1723 / \mathbf{I I} / \mathbf{f} / 22$.

Abb. 4. Gesuch des Abdeckers Martin Leyssner auf Auszahlung eines Schuldbetrags für die Reinigung der Wachstube in den Jahren 1705-1718 (1723). NA, SČM, 1723/II/f/22. 
Specifikati dila Nocžniho od werbowane warty na Staroměstskym Haubtwachu ode dne 21. May 1705 až do dne 12. Aprilis leta 1718

\begin{tabular}{|c|c|c|c|}
\hline rok & datum & počet fůr & odměna \\
\hline \multirow[t]{4}{*}{1705} & 21.5. & 17 & \\
\hline & 6. 8. & 18 & \\
\hline & 24. rrij & 21 & \\
\hline & Celkem & 56 & 28 zlatých \\
\hline \multirow[t]{6}{*}{1706} & 26.1. & 21 & \\
\hline & 19. 3. & 17 & \\
\hline & 19. 7. & 16 & \\
\hline & 26. 10. & 14 & \\
\hline & 27. 10. & 18 & \\
\hline & celkem & 86 & 43 zlatých \\
\hline \multirow[t]{6}{*}{1707} & 16. 2. & 17 & \\
\hline & 28.4. & 14 & \\
\hline & 21.6. & 18 & \\
\hline & 1. 10. & 19 & \\
\hline & 2. 10 . & 21 & \\
\hline & celkem & 89 & $\begin{array}{l}44 \text { zlatých, } \\
30 \text { krejcarŭ }\end{array}$ \\
\hline \multirow[t]{5}{*}{1708} & 4. 3. & 17 & \\
\hline & 8.6. & 21 & \\
\hline & 6. 9. & 18 & \\
\hline & 16.12. & 21 & \\
\hline & celkem & 77 & $\begin{array}{l}38 \text { zlatých, } \\
30 \text { krejcarú }\end{array}$ \\
\hline \multirow[t]{6}{*}{1709} & 6. 1. & 18 & \\
\hline & 27.3. & 19 & \\
\hline & 24. 1. & 17 & \\
\hline & 19.7. & 15 & \\
\hline & 10. 10. & 21 & \\
\hline & celkem & 90 & 45 zlatých \\
\hline \multirow[t]{5}{*}{1710} & 22.1. & 14 & \\
\hline & druhá noc & 17 & \\
\hline & 16.4. & 18 & \\
\hline & 13.8. & 25 & \\
\hline & celkem & 74 & 37 zlatých \\
\hline \multirow[t]{2}{*}{1711} & 6.3. & 17 & \\
\hline & 11. 8. & 20 & \\
\hline
\end{tabular}

\begin{tabular}{|c|c|c|c|}
\hline rok & datum & počet fůr & odměna \\
\hline & 19. 12 . & 14 & \\
\hline & 20. 12 . & 14 & \\
\hline & celkem & 65 & $\begin{array}{l}32 \text { zlatých, } \\
30 \text { krejcarů }\end{array}$ \\
\hline \multirow[t]{5}{*}{1712} & 8.3. & 17 & \\
\hline & 9. 3 . & 17 & \\
\hline & 17. 7. & 16 & \\
\hline & 19. 11. & 14 & \\
\hline & celkem & 63 & $\begin{array}{l}31 \text { zlatých, } \\
30 \text { krejcarů }\end{array}$ \\
\hline \multirow[t]{4}{*}{1713} & 15. 2 . & 20 & \\
\hline & 18.7. & 14 & \\
\hline & 9. 11. & 20 & \\
\hline & celkem & 54 & 27 zlatých \\
\hline $\begin{array}{c}\text { W letu } 1714 \\
\text { z czela a zauplna } \\
\text { gsem zaplaczeny } \\
50 \text { zlatých, kdež } \\
\text { gsem až na wodu } \\
\text { dělati dal. }\end{array}$ & & & \\
\hline \multirow[t]{3}{*}{1715} & 18.9. & 15 & \\
\hline & 19. 12 . & 14 & \\
\hline & celkem & 29 & $\begin{array}{l}14 \text { zlatých, } \\
30 \text { krejcarů }\end{array}$ \\
\hline \multirow[t]{3}{*}{1716} & 25.1. & 6 & \\
\hline & $\begin{array}{c}\text { Na tato kde } \\
\text { gsem tak } \\
\text { pomalu po } 4 \text {, } \\
5 \text { a } 6 \text { forach } \\
\text { dal wywažet } \\
\text { a nobrž } \\
\text { wynásset ged- } \\
\text { no k druhému } \\
\text { sprawedlivě }\end{array}$ & 24 & \\
\hline & celkem & 30 & 15 zlatých \\
\hline \multirow[t]{2}{*}{1717} & $\begin{array}{c}\text { Dal gsem } \\
\text { wywažet na } \\
\text { Obochu Poko- } \\
\text { likrate po } 5,6 \\
\text { forach, czož } \\
\text { wynassi }\end{array}$ & 30 & \\
\hline & celkem & 30 & 15 zlatých \\
\hline \multirow[t]{2}{*}{1718} & $\begin{array}{l}\text { Třikrát po } 6 \\
\text { forách }\end{array}$ & 18 & 9 zlatých \\
\hline & 12.4. & 9 & $\begin{array}{l}4 \text { zlaté, } \\
30 \text { krejcarů }\end{array}$ \\
\hline celkem & & 752 & 376 zlatých \\
\hline
\end{tabular}

Tab. 1. Specifikace pohledávek pohodného Martina Leyssnera (1723). NA, SČM, 1723/II/f/22.

Tab. 1. Spezifikation der Forderungen des Abdeckers Martin Leyssner (1723). NA, SČM, 1723/II/f/22.

dělníci, kteři měli potrubí zavádět mnohdy do již dokončených náspů a armovaných zdí, k čemuž bylo třeba velké opatrnosti a zkušeností, přesto došlo k poškození šancí kvůli nekvalifikované práci. Konkrétně v roce 1720 musel zasáhnout dokonce císař, který nechal plošně zpř́ísnit dohled nad těmito dělníky (NA, SČM, 1720/V/d/051). V dubnu 1730 bylo naplánováno vystavění nové 
klenuté štoly na Hradčanech u Strahovské brány, do níž bylo svedeno stávající odvodnění, které se původně mělo kvůli pokračujícím stavebním pracím zrušit (NA, SČM, 1730/V/d/18).

Problémy zpo̊sobovalo také financování stavby a proplácení všech platů. Opevnění Malé Strany bylo financováno z extraordinární daně - speciálního poplatku za každé vědro prodaného vína, piva a pálenky. $O$ penězích na stavbu rozhodoval zemský sněm, který od 60 . let 17 . století vyčleňoval na stavbu opevnění ze zemských daní povětšinou 20 až 30 tisíc zlatých ročně. Rozpočet tak byl jasně daný. Větší potíže s nedostatkem peněz měli na druhém břehu Vltavy, kde se náklady hradily z tzv. militare, běžné daně určené pro vojenské účely. Výši přidělených peněz kontroloval panovník. Na počátku 18. století bylo pro staroměstsko-novoměstské stavitele stále těžší získat další prostředky a stavba tak víceméně ustala. Na Vyšehradě bylo nicméně zjištěno, že je možné zcela volně dojít jak ke skladu prachu, tak ke zbrojnici! Došlo tak i na návrh zaplatit nejnutnější opravy z peněz určených na malostranské opevnění a později vše dorovnat. Přesto i relativně dobře financovaná malostranská fortifikace měla své potíže. Stále se urgovala výplata peněz jak dělníkům, tak i samým stavitelům, jak na to ukazuje např. zpráva inženýra pro fortifikační komisi. Píše se v ní, že pokud komisaři chtějí, aby stavba opevnění pokračovala dle plánu a mohly se použít již sněmem odsouhlasené i dříve uvolněné částky, musejí být peníze ,fleissig a tempo assignirt und ausgefollget", a to vrchnímu staviteli Scottimu 200 zlatých a staviteli Dientzenhoferovi 300 zlatých (NA, SČM, 1734/III/d/21).

Stavba se také stále prodlužovala a oddalovaly se termíny dokončení. Tak například měla být $\mathrm{v}$ roce 1733 dokončena a uzavřena podle plánu kurtina mezi bastiony u Újezdské brány, sv. Jakuba a sv. Karla, nicméně na počátku roku 1734 bylo na tomto úseku zdi ještě mnoho práce a bylo třeba termín dále posunout. $Z$ formulace navíc vyplývá, že nemuselo jít o první posunutí dokončovacího termínu (NA, SČM, 1734/III/d/20).

\section{Život s hradbou}

I s hotovou a fungující fortifikací se každý z obyvatel města vyrovnával po svém, někomu mohla vadit, jiný se ji snažil využít, pro jiné se nové objekty opevnění staly místem výkonu práce, někteří pražští měštané se také stali dodavateli zboží a služeb s hradbou souvisejících.

Pražští řezníci se rychle naučili fortifikaci využít pro svůj zisk a pásli na nově vystavěných či opravených vysokých zemních stavbách skot a další dobytek, a to nejen svůj, ale vyháněli tam za úplatu i dobytek pro jiné obyvatele. Dělo se tak jak na Malé Straně, tak na Novém Městě. U některých bran tudíž docházelo pod kopyty dobytka k erozi zemních těles, materiál z opevnění byl během dešt'ů splachován až do bran. Např́iklad u Strahovské brány byla roku 1736 zrovna renovována berma, ale kvůli pastvě už byla zcela zničená - „niederlegen“, stejně tak byly zcela rozbité nová berma a eskarpa vybudované u Obilné brány na Novém Městě. Obecně pastva způsobovala velké škody, ovšem řezníci, kteří byli nejednou z opevnění vyhnáni, se tam další den objevili znova. Proto byl zpřísněn zákaz a hlídky u bran měly každého řezníka zostra (,scharf“) hnát. Vzhledem k tomu, že dekret se v této věci několikrát opakoval, lze předpokládat, že dobytek na hradbách zůstával běžným výjevem (NA, SČM, 1736/X/d/66).

$\mathrm{Na}$ čištění prostor patřících k opevnění byl najímán pohodný. Na tzv. „,noční práce“ při vyklízení konkrétně staroměstské strážnice byl najímán od roku 1705 staroměstský ras Martin Leyssner, atestovaný tamním šestipanským úřadem (pro přehled jeho činnosti v letech 17051718 viz tab. 1). Za jeho práci mu nebylo ovšem dlouho vůbec zaplaceno. Leyssner urgoval proplacení částky několikrát, naposledy roku 1720. Ve své žádosti komisařům vše formuloval následovně: „(...) za to nejponiženěji prosím, abych již v tolika proběhnutých letech jedenkráte k svému zaplaceni prijíti a tady také po ten čas jinde rozdělané dluhy a Outraty zapraviti mohl, tu kde náleží, milostivě naříditi dáti, sobě oblibiti ráčite. Za kteroužto velkou milost bůch sám odplatitelem bude. Na mých nehodných modlitbách nejponíženěji trvajíci Martin Leyssner, pohodný Staroměstský" (viz obr. 4). Martin Leyssner měl štěstí, komisaři (František Josef Černín a Václav Arnošt Markvart z Hrádku) uznali jeho žádost jako oprávněnou. Leyssner měl sepsat všechny své požadavky, tedy který den, respektive noc, a kolik fưr odvezl z čištěných prostor. Za 
odvezení jedné fưry si pohodný účtoval 30 krejcarů. Celková částka, kterou požadoval, činila za léta 1705 až 1718 celkem 376 zlatých 24 krejcarů. Tyto peníze mu byly také následně poukázány (NA, SČM, 1723/II/f/22). Díky Leyssnerově stížnosti si můžeme udělat představu o tom, kolik odpadu bylo nutné odvážet z jednoho objektu i jak často, a to poměrně dlouhodobě, v průběhu několika let (viz tabulka).

Na některé aktivity, které doprovázely provoz hradeb, si stěžovali obyvatelé města i majitelé pozemků v okolí. I když jim pozemky nebyly v souvislosti s výstavbou zabrány, ponechané zahrady, vinice či pole jim však blízkost opevňovací linie dlouhodobě znehodnocovala. Zahradníci, kteří měli svá pole a zahrady za branami města, si stěžovali, že jejich pozemky jsou zasypávány sutí a rumem $\mathrm{z}$ př́íkopů a ze zbořených staveb, které se původně na půdorysu nového opevnění nacházely, např. i staré strážnice, mosty a součásti středověkého opevnění, které už nebyly dále zapotřebí. Navíc tak bylo činěno bez ohledu na roční období, tedy na to, zda na políčkách a zahradách je zrovna zaseto či zasázeno. Samozřejmě docházelo ke škodám na výpěstcích obilí i zeleniny („Küchelgartenspeisen“), někteří ze zahradníkủ byli těmito praktikami dokonce ohroženi existenčně. Nic ovšem nenasvědčuje tomu, že by se po jejich stížnosti zásadně změnil způsob nakládání s nepotřebnou hlínou či sutí (SOA T).

$\mathrm{Na}$ druhou stranu, ze zakázek na opevňovacích pracích netěžili pouze pražští stavitelé a př́ibuzné profese, ale i mistři zdánlivě nesouvisejících řemesel. Například malostranský čalouník Václav Taussig získal roku 1723 zakázku na 245 nových matrací s mnoha polstry, 221 dek z nové vlny, 166 nových polstrů bez matrací a 23 nových dek ze staré fortifikační vlny a ze starých matrací měl vyrobit 118 nových, 82 již užívaných polstrů pak mělo být vyspraveno a nově naplněno žíněmi (NA, SČM, 1723/II/f/22). Uvedený př́íklad dobře ilustruje snahu o maximální znovuvyužití vojenského materiálu; ve stejné záležitosti je dokonce zachycen př́kaz důstojníkům, aby nedopustili ztráty žíní z rozedraných polstrů (SOA T).

\section{Opravy opevnění}

Stavba barokního opevnění Prahy představovala několik desetiletí trvající proces. Zatímco některé části ještě nebyly dokončeny, jiné už mohly stát po mnoho sezón. Pokud jim nebyla věnována dostatečná péče, docházelo k jejich poškození, většinou vlivem povětrnostních podmínek. Ze zpráv dozorčího inženýra Norberta Theodora Lincka, nap̌r. pro rok 1733, se dozvídáme následující: bastion sv. Máří Magdaleny (obr. 1:XIX) je už sice hotov, až na jednu část „Eckeabwerts des Bergs", a stejně tak je uzavřena zed' mezi Strahovským bastionem a bastionem sv. Františka (obr. 1:IX, X), kde už jsou ,face, flank i cortina“, ale na mnoha místech jsou ve zdi díry nebo se zed’ rozestupuje, takže nároží flanku se zcela zř́itilo (SOA T).

V podobně neutěšeném stavu se pak nacházel i Strahovský bastion (obr. 1:IX), v roce 1733 se připomíná, že poškození cihlové armatury deštovou vodou se $\mathrm{v}$ předešlém roce nestačilo opravit. Naopak u bastionu Hvězda a bastionu Panny Marie (obr. 1:XI, XII) se u „hlavní zdi“ nakupila země, kterou bylo třeba využít na vytvoření glacis a kontreskarpy.

Průběžné úpravy pak samozřejmě vyžadovaly i různé součásti strategické infrastruktury, a i jí byla věnována pozornost fortifikačních úředníků. $Z$ jejich popudu vzešel návrh, aby byl městský vodovod prodloužen a zaveden až do města, protože v případě, že by někdo poškodil nezakrytou vodovodní rouru a např. založil požár, nebude voda na uhašení. Inženýr Linck dokonce navrhl vybudovat na přivedené vodě mlýn (NA, SČM, 1734/III/d/21-23).

Objevovaly se samozrrejmě také nové návrhy, jak vojenskou hodnotu pražské fortifikace navýšit, byly vyhotovovány nové plány, které ale nakonec ze strategických či finančních důvodů zůstaly nerealizovány. Jedním z neuskutečněných plánů byl projekt inženýra Lincka na vybudování obranné zdi Malé Strany i kolem Vltavy, od bastionu sv. Jana (obr. 1:I) k bastionu sv. Ignáce (obr. 1:XX), a pro průchod mělo být ponecháno jen několik branek, které by byly otevřeny pouze ve dne (NA, SČM, 1734/III/d/21, 22). U plánů zůstalo i v př́ípadě zamýšlené citadely Malé Strany, která měla stát na Petř́ně či na Strahově (NA, SČM, 1732/IV/d/29). 


\section{2 - jeden rok v životě hradby}

Pro rok 1732 máme dochovaný vynikající pramen, který umožňuje mikrohistorický vhled do stavebních a dalších aktivit spojených s opevněním pražského levobřeží. Je jím zpráva inženýra Lincka pro prezidenta fortifikační komise hraběte Josefa Serényiho (SOA T). Dokument nadepsaný prostě jako „Project“ obsahuje plán prací na malostranské fortifikaci pro rok 1732:

- U Strahovské brány (obr. 1:4) je zapotřebí vybudovat krytou cestu, předprseň a glacis, k čemuž bude zapotřebí značné množství navážené zeminy. Nezbytné bude vykopat kynetu u přemostění.

- Pod strahovským úbočím bude třeba vyzdít vnější stěnu příkopu, nebot' se samovolně zasypával. Do budoucna bude i zde třeba vybudovat předprseň a glacis. Práce povede stavitel Scotti a bude na ně uvolněno 5800 zlatých.

- Za Písečnou branou (obr. 1:6) dojde v roce 1732 k uzavření hlavní zdi, už je potřeba jen postavit dva flanky, kurtinu a cihelnou líc face.

- Na bastionu sv. Máří Magdaleny (obr. 1:XIX) bude nezbytné přezdít rozpadající se šance i prŕíkopy. Vznikal zde také problém s deštovou vodou, která stéká k základům opevnění a narušuje zdi, tj. bude třeba vybudovat kynetu a odvodňovací strouhu, které odvedou vodu mimo opevnění, kolem jezuitské zahrady (obr. 1:7) dolů do Vltavy.

- U bastionu sv. Tomáše (obr. 1:XVIII) směrem od Hradu není žádný pramen, sedm mužů zde vykope studnu, nebot' dosud zde lidé museli chodit pro vodu velmi daleko. Tyto práce bude provádět stavitel Dietzenhofer.

\section{Závěr}

Jak ukázala předcházející stat', barokní fortifikaci pražského levobřeží můžeme chápat jako hmotné vyjádření významu opevněného území jako duchovního a politického centra Českého království. Nositeli této ideje byly české stavy spolu s habsburským panovníkem. Jádro společenského impaktu tohoto opevnění tedy v zásadě netvořila jeho hmotná podstata a ani primární (vojenská) funkce. Konkrétní stavebnětechnické provedení hradby pak nebylo v žádném případě konstantou, šlo o výsledek mnoho desetiletí trvajícího procesu, do kterého se zapojila řada aktérů, minimálně v jednom zdokumentovaném př́ípadě šlo dokonce o privátní iniciativu. Ve vztahu k sídlu, které hradba obepínala, vlastně nikdy svou obrannou úlohu nesplnila. Z hlediska komunity, která pražské levobřeží vnímala jako své sídliště, a nikoliv jako státně-symbolický okrsek, musela být vnímána přinejlepším ambivalentně, jako zatěžující prvek, který může přinést i jisté ekonomické výhody a prŕiležitosti, pokud by rušivé vlivy spojené s hradbou nepřevažovaly. Platnost těchto tvrzení dokládají i archiválie z období mezi francouzským obsazením Prahy roku 1744 a zrušením tzv. zemských pevností roku 1749. Na jedné straně hovoří o nutných opravách i možném vylepšení fortifikačních prvků (NA, SČM, 1744/VIII/h/16), na druhé straně konstatují, že pokud by hrozilo opakování scénářů kampaní let 1741 a 1744, bude lépe, když Prahu jako pevnost neutralizuje, tedy poboří její fortifikace, samo habsburské vojsko (NA, SČM, $1745 / \mathrm{VII} / \mathrm{d} / 3)$ !

Na základě tohoto pohledu na fenomén hradby je možno zformulovat požadavek na vytvoření komplexního teoretického modelu zahrnujícího společenské i fyzické entity a jejich vztahy, který by postihoval historický proces života hradby od její ideové koncepce k výstavbě (determinované lokálními podmínkami), volbu konkrétních fortifikačních prvků, jejich konstrukci, výstavbu, chátrání, opravy, válečná poškození, cílená rozšiření, tedy veškeré stopy lidských aktivit spojených s areálem hradby, a to až po ztrátu funkce, fyzický zánik i ztrátu významu prostorového, právního i strategického členění prostoru vyjádřeného právě fortifikační linií. Lze vyjádřit naději, že vytvoření komplexu zásadních teoretických otázek i pojmů relevantních pro potenciálně mimořádně širokou badatelskou komunitu může integrovat např. archeology pravě- 
ku a středověku, specialisty na vrcholně středověkou a raně novověkou pevnostní architekturu, historiografy světových konfliktů 20. století i zájemce o tzv. železnou oponu.

Text je výstupem projektu GA UK 656314 „České místodržitelství za vlády Karla VI.“ řešeného na Katedře pomocných věd historických a archivního studia FF UK v Praze.

\section{Prameny, zdroje a literatura}

BARTOŠKOVÁ, A., 2014: Budeč: Významné mocenské centrum prvních Přemyslovců. Praha.

BARTOŠOVÁ, V.-HERICHOVÁ, I.-KAŠIČKA, F.-TOMKOVÁ, K., 2010: Barokní opevnění Prahy v trase stavby tunelu Blanka, ZPP 70, 239-247.

BOHÁČOVÁ, I. a kol., 2003: Stará Boleslav. Přemyslovský hrad v raném středověku. Praha.

BURKE, P., 2011: Co je to kulturní historie? Praha.

ČECH, P., 2008: Souhrn současného stavu poznání Žatce v raném středověku - Der gegenwärtige Erkenntnisstand zu Saaz (Žatec) im Frühmittelalter, AR LX, 36-60.

ČIHÁKOVÁ, J.-HAVRDA, J., 2008: Malá Strana v raném středověku. Stav výzkumu a rekapitulace poznání - Malá Strana (Lesser Town) in Prague in the Early Middle Ages. The current status of archaeological excavations, AR LX, 187-288.

DANIEL, U., 2005: Kompendium Kulturgeschichte. Theorien, Praxis, Schlüsselwörter. Frankfurt am Main.

DRESLER, P., 2011: Opevnění Pohanska u Břeclavi. Brno.

ETTEL, P., 2001: Karlburg - Roßtal - Oberammerthal. Studien zum frühmittelalterlichen Burgenbau in Nordbayern. Frühgeschichtliche und provinzialrömische Archäologie. Materialien und Forschungen 5. Rahden/Westf.

HASILOVÁ, P., v přípravě: Místodržitelská fortifikační komise pro Malou Stranu a Cheb.

HAVRDA, J.-TRIML, M., 2013: Nebovidy. Středověká osada v pražském podhradí. Archeologické prameny k dějinám Prahy 6. Praha.

JEŘÁB, J., 2000: Nálezová zpráva z archeologického výzkumu prováděného formou dohledu ve vojenském areálu Pohořelec, čp. 120 a 121 v Praze 6 - Hradčanech, ulož. v Archivu nálezových zpráv ARÚ AV ČR, Praha, v. v. i., TX200101546.

KAŠIČCKA, F.-LACINGER, L., 2005: Hradčanské hradby v rozsahu bastionů č. XI-XIV, stavebně-historický průzkum, GŘ NPÚ, PPOP-996-5-531.

KORTUS, O., 2008: Cheb a okolí za saského vpádu v letech 1631 a 1632, Sborník muzea Karlovarského kraje 16, 95-122.

KOS, L., 2012: Raně středověké fortifikace s čelní kamennou plentou ve střední Evropě, Studia Mediaevalia Pragensia 11, 117-175.

KUBŮ, F., 2006: Chebský městský stát. Počátky a vrcholné období do počátku 16. století. České Budějovice.

KUPKA, V. a kol., 2001: Pevnosti a opevnění v Čechách na Moravě a ve Slezsku. Praha.

NA, SČM: Národní archiv České republiky, fond Staré české místodržitelství, 1563-1751, NAD 181.

NEUSTUPNÝ, E., 2007: Vymezení archeologie. In: Pravěký svět a jeho poznání. Archeologie pravěkých Čech 1 (Kuna, M., ed.), 11-22. Praha.

PROCHÁZKA, R., 2009: Vývoj opevňovací techniky na Moravě a v českém Slezsku v raném středověku. Brno.

RAZÍM, V., 2001: Městské opevnění na Petříně. In: Zavřel, J. a kol., Pražský vrch Petř́n, 133-143. Praha - Litomyšl.

- 2001a: Středověké hradby města Nymburka. Nymburk.

RICOEUR, P., 1997: Teória interpretácie. Diskurz a prebytok významu. Bratislava.

RICHTER, M., 1982: Hradišt’ko u Davle. Městečko ostrovského kláštera. Praha.

SALAČ, V., 2011: K výzkumu oppid v Čechách a na Moravě v minulém tisíciletí, ASČ 15, 463-474.

SIEGL, K., 1918: Die staatsrechtliche Stellung des Egerlandes. Eger.

SLAVÍK, J. a kol., 2014: Bastionové pevnosti - průzkumy a opravy. Ústí nad Labem.

SOA T: Státní oblastní archiv v Třeboni, Rodinný archiv Serényiů de Kis Serényi (1577) 1739-1799, NAD 590 , karton 3, sign. III D 10.

VLČEK, P.-ČIHÁKOVÁ, J., 1999: Brány, opevnění, věže. In: Vlček, P. a kol., Umělecké památky Prahy III. Malá Strana, 113-121. Praha. 


\section{Zusammenfassung}

Stadtmauern als kulturhistorisches Problem: die barocke Befestigungsanlage des linken Prager Moldauufers in der schriftlichen Hinterlassenschaft der Fortifikationskommission der Böhmischen Statthalterei

Eine der Konstanten der mitteleuropäischen und demnach auch der tschechischen Archäologie ist ein langfristiges Interesse an festen Befestigungsanlagen komplexer Siedlungsareale (z.B. von Burgwällen, Oppida oder Städten). Dabei kann man freilich behaupten, dass diesem Phänomen in Fachtexten und mehr oder weniger förmlichen Diskussionen überwiegend aus zwei Aspekten Beachtung geschenkt wird: zum Einen handelt es sich dabei um Fragen, die mit ihrer Konstruktion zusammenhängen, zum Anderen um das Studium von befestigten Arealen als solche, wobei eine Fortifikation in diesem Fall primär als ihr formales Kriterium verstanden wird, im Falle von urzeitlichen und frühmittelalterlichen befestigten Fundstellen sogar häufig als einzige verständliche Struktur, durch welche ein Burgwall, eine Viereckschanze, ein Oppidum oder eine frühmittelalterliche Burg konstituiert werden. Einem Verständnis, das Befestigungen als eigene, besonders geprägte Areale menschlicher Aktivitäten ansieht, findet man jedoch lediglich bei ausgedehnteren Siedlungsballungen im Frühmittelalter, bei ausgeprägten Konzentrationen frühmittelalterlicher, befestigter Fundstellen, bei neuzeitlichen Festungen oder in mittelalterlichen und neuzeitlichen Städten gewidmeten Fachtexten. Dabei handelt es sich jedoch durchweg lediglich um einen Ad-hoc-Ansatz, der durch die Profile und Kompetenzen der verfügbaren Quellen, oder umgekehrt, durch die jeweils geklärte Frage gegeben ist.

Man kann festhalten, dass die Wehr- oder Stadtmauer von der tschechischen Archäologie bisher nicht als Problem des Studiums der Kulturgeschichte thematisiert wurde. Für diese Tatsache lassen sich offensichtlich gleich mehrere Ursachen benennen: zum Einen spielt zweifelsohne die Beharrlichkeit traditionell vertretener Auffassungen eine Rolle, die darüberhinaus laufend durch Synergien mit vergleichbaren Ansätzen aus den Nachbarländern bestärkt werden, zum Anderen die Betrachtung der Entstehung und des Untergangs von Befestigungen durch das Prisma der archäologischen Ereignisse, und nicht zuletzt die immer noch sehr enge konzeptuelle Fessel zwischen einer Befestigung und dem Siedlungsareal, das es umschließt. An dieser Stelle sei an die revolutionären Erkenntnisse erinnert, die im Zusammenhang mit den latènezeitlichen Zentren gewonnen wurden, nachdem Anfang der neunziger Jahre Fundstellen des Typs Roseldorf-Němčice bzw. Lovosice identifiziert wurden.

Für die Fallanalyse wurden im Nationalarchiv der Tschechischen Republik und im Staatlichen Gebietsarchiv in Třeboň aufbewahrte Dokumente herangezogen, die von der Fortifikationskommission der Böhmischen Statthalterei stammen und überwiegend zur Regierungszeit von Kaiser Karl VI. (1685-1740) entstanden sind. Sie halten die allgemeine Supervision über Bau und Funktionsfähigkeit der Bastionärbefestigung der Prager Kleinseite und des Hradschins fest, und zwar im Hinblick auf die Finanzverwaltung und die verschiedensten Beschwerden der Bevölkerung und Eigentümer der betroffenen Grundstücke. Dank dessen war es möglich, einen Einblick in die Vorbereitungsarbeiten und Einschränkungen zu bekommen, die mit dem Bauwerk, der eigentlichen Errichtung der Befestigung, dem Bezug der lokalen Gemeinschaften zur bereits fertigen Stadtmauer und wie diese darin eingebunden waren zusammenhängen. Die Agenda der Statthaltereikommission umfasste ferner ein Zeugnis über Reparaturen der Stadtmauer, und es war sogar möglich, die Bau- und Reparaturaktivitäten an der Befestigungslinie für ein konkretes Jahr (1732) zu rekonstruierten.

Aufgrund dieser Betrachtungsweise des Phänomens Wehr- bzw. Stadtmauer kann die Forderung nach der Schaffung eines komplexen Systems gesellschaftlicher und physischer Entitäten und deren Beziehungen formuliert werden, welches den historischen Prozess einer Wehr- oder Stadtmauer, angefangen von ihrem gedanklichen Konzept bis hin zum Bau (determiniert durch die lokalen Bedingungen), die Wahl der konkreten Fortifikationselemente, deren Konstruktion, Bau, Verfall, Wiederinstandsetzung, Kriegschäden, gezielte Verbreitung, d.h. jegliche Spuren 
menschlicher Aktivitäten erfasst, die mit dem Areal der Wehr- bzw. Stadtmauer verbunden sind, und zwar bis hin zum Verlust der Funktion, dem physischen Untergang und dem Bedeutungsverlust der räumlichen, rechtlichen sowie strategischen Gliederung des gerade durch die Fortifikationslinie zum Ausdruck gebrachten Raumes. Man kann die Hoffnung äußern, dass die Schaffung eines Komplexes von grundsätzlich theoretischen Fragen sowie von Begriffen, die für eine potenziell außerordentlich breite Forschergemeinschaft relevant sind, etwa Archäologen der Urzeit und des Mittelalters, Experten für die hochmittelalterliche und frühneuzeitliche Festungsarchitektur, Historiographen der globalen Konflikte des 20. Jahrhunderts und Interessierte am sogenannten Eisernen Vorhang miteinbeziehen kann.

Der vorliegende Text ist ein Forschungsergebnis des am Lehrstuhl für historische Hilfswissenschaften und archivalische Studien der Philosophischen Fakultät der Karls-Universität in Prag durchgeführten Projekts GA UK 656314 „Böhmische Statthalterei unter der Herrschaft von Karl VI.“.

Mgr. Jan Hasil, Archeologický ústav AV ČR, Praha, v. v. i., Letenská 4, 11801 Praha 1, Česká republika, hasil@arup.cas.cz

Mgr. Pavla Hasilová, Katedra pomocných věd historických a archivního studia FF UK, nám. Jana Palacha 2, 11638 Praha 1, Česká republika, pavla.hasilova@seznam.cz 
